the USSR and the Union Republics. It includes amendments and revision to bring the text, originally introduced on December 25, 1958, in line with the new USSR Constitution. The revised text is published in the Russian language in Vedomosti Verkhovnogo Soveta SSSR, July 2, 1980.

On the same date the Supreme Soviet of the USSR promulgated a new text of the Statute on Military Tribunals, originally enacted on December 25, 1958. The new text, containing amendments required of the USSR Constitution of 1977 , is also published in the Russian language in Vedomosti Verkhovnogo Soveta SSSR, July 2, 1980.

\title{
USSR SOCIALIST PROPERTY
}

A useful description of socialist property appears in the analysis of the "juridical person" within the framework of article 11 of the Fundamentals of Civil Code in a recent book on the Fundamentals of Soviet Law, prepared by a collective of authors and published in the Russian language in 1979. It says (pp. 37-40 and 61-70):

(1) Property may belong to an organization on the basis of ownership, e.g., kolhozes, and other cooperative organizations, or attached (given) to it for the purpose of performing prescribed social (economic) functions. Thus, state organizations (enterprises, amalgamations, institutions), not being owners of property, nevertheless have state property attached to them, which they use to fulfill obligations imposed on them by the state. The indications of their proprietary autonomy is indicated by the recognition of their separate fixed and circulating capital and their own budget.

(2) There is a variety of juridical persons in the U.S.S.R. They include state, enterprises, amalgamations of such enterprises, institutions, kolhozes, other cooperatives, and social organizations.

(3) There is an indication of an ultra vires principle in that such juridical persons may have property relating only to their legally defined functions. Having property outside the scope of their respective purposes is illegal.

(4) A juridical person ceases to exist in the event of amalgamation or liquidation. In the event of amalgamation the property passes to the new juridical person. Upon liquidation the property is transferred to other organizations in accordance with the order of the liquidating commission or reverts to the appropriate state organ. 